\title{
Allergen-Specific Immunotherapy in Patients 55 Years and Older: Results and Review of Literature
}

\author{
Eduardo Baptistella ${ }^{1}$ Sergio Maniglia ${ }^{1}$ Diego Augusto Malucelli ${ }^{1}$ Daniel Rispoli ${ }^{1}$ \\ Thanara Pruner de Silva ${ }^{1}$ Fernanda Miyoko Tsuru ${ }^{1}$ Renata Vecentin Becker ${ }^{1}$ Gustavo Bernardi ${ }^{1}$ \\ Daniela Dranka ${ }^{1}$ Bruno Ferraz ${ }^{1}$
}

${ }^{1}$ Centro Médico Especializado Baptistella (CMEB), Curitiba/PR, Brazil Int Arch Otorhinolaryngol 2013;17:375-379.
Address for correspondence Fernanda Miyoko Tsuru, CMEB, Eduardo Baptistella Avenida João Gualberto, 1795, Conjunto 01 Juvevê, Curitiba/PR, CEP 80 030-001, Brazil (e-mail: feu.tsuru@yahoo.com.br).

\begin{abstract}
Introduction Over the years the immune system suffers many morphologic and functional alterations, which result in a peak of function in puberty and a gradual decrease in the elderly.

Aim Treat patients 55 years or older with allergic rhinitis with immunotherapy and then analyze the response to allergens.

Materials and Methods From June 2009 to July 2010, 104 charts of patients 55 years or older with allergic complaints were evaluated. The patients were selected by anamnesis, physical examination, and otorhinolaryngologic exam. The patients had cutaneous test for mites before and after 1 year of sublingual specific immunotherapy. The cutaneous response was classified as negative (absent), light, moderate, or severe. Results Before vaccination, 42 (40.4\%) patients were classified as having a severe form of allergy and 62 (59.6\%) as having a moderate allergy. After the specific therapy, 40 (38.4\%) patients were classified as negative (absent), 37 (35.6\%) as light, $19(18.3 \%)$ as moderate, and $8(7.7 \%)$ as severe responses.

Conclusion Immunotherapy, a desensitization technique, is indicated in cases which

Keywords

- immunotherapy

- aged

- rhinitis patients cannot avoid the exposure to allergens and in situations where pharmacologic therapy is not ideal. Specific immunotherapy to treat the allergic rhinitis in elderly patients was efficient and had no collateral effects, and in addition to the clinical benefit, improvement in the cutaneous test could also be observed.
\end{abstract}

\section{Introduction}

Over the years, the immune system-responsible for combating allergy symptoms in the organism-suffers many morphologic and functional alterations. The immune system helps the human antigenic constitution. The immune system consists of cells, molecules, and genes that interact with other systems for the protection of the organism. This system is composed of innate immunity, which represents the nonspecific natural resistance of human beings, and adaptive immu- nity (immunity proper)-more specifically, memory and higher-efficiency immunity.

The immune system changes and peaks in puberty and then declines gradually in the elderly, ${ }^{1}$ known as immunosenescence. There is a great interaction between the immune and nervous systems, and this means there is an exacerbation of immune disorders and depression of the normal functions of the immune system. ${ }^{2}$ Apparently, the elderly are more vulnerable to these events. ${ }^{3}$ received

November 6, 2012

accepted

June 13, 2013
Copyright $\odot 2013$ by Thieme Publicações DOI http://dx.doi.org/ Ltda, Rio de Janeiro, Brazil

10.1055/s-0033-1353138. ISSN 1809-9777. 
The decline of immunity is related to changes that occur in each of the cell types that make up the immune system. The T cells responsible for cellular immunity show reduction of early events in their signaling cascades, ${ }^{4,5}$ resulting in decrease of activity. Cytokines, key mediators of the immune response that control various cellular functions (proliferation, differentiation, and cell death), ${ }^{6}$ become imbalanced and increase the susceptibility of the organism to infections caused by viruses and extracellular bacteria. ${ }^{7}$ These defects in regulation of the immune response can also lead to an increase in autoimmune diseases. ${ }^{8,9} \mathrm{~B}$ cells are responsible for humoral immunity and show qualitative and quantitative changes in their repertoire, which are characterized by low antibody response and decreased high-affinity antibodies to the aging of the organism. ${ }^{10}$

Allergic rhinitis is a disorder linked to the immune system and may be associated with other allergic manifestations such as bronchial asthma, dermatitis, conjunctivitis, among others. ${ }^{11}$ This disease affects, in a greater or lesser degree, all ages, with the prevalence of $25 \%$ in the general population. ${ }^{1,12,13}$ It is even reported among young people; however, with the changing age pattern, it is estimated that there are a greater number of diagnoses of this entity in the elderly. It is also estimated that one third of elderly people suffer from some type of allergic symptoms.

Patients with allergic rhinitis have type 1 hypersensitivity reaction, with persistent inflammation of the nasal mucosa. Inflammatory cells such as eosinophils and mast cells, and mediators such as chemokines and cytokines, participate in the pathophysiology. The pattern developed by the immune response in atopic patients is Th2 with production of cytokines such as interleukin (IL)-4, IL-5, and IL-10. ${ }^{14-16} \mathrm{~B}$ lymphocytes from individuals previously sensitized to specific allergens produce IgE antibodies that bind to the surface of mast cells and basophils by high-affinity receptors for the Fc portion. After new contact, the allergen binds IgE on the surface of mast cells, promoting the same degranulation, with release of histamine, lipid-derived substances (prostaglandins and leukotrienes), and cytokines. Eosinophils are also recruited to the inflammatory site and release a cationic protein with amplification of the allergic response. ${ }^{17}$ In other words, allergic rhinitis is an inflammation of the nasal mucosa, induced by exposure to allergens after sensitization, which trigger an inflammatory response mediated by IgE, resulting in chronic or recurrent symptoms. ${ }^{11}$

The diagnosis is basically clinical. An appropriate otorhinolaryngologic examination identifies without many difficulties signs of rhinitis, such as hypertrophy and pallor of the inferior turbinates and hyaline secretion. ${ }^{18}$ However, additional tests may help establish the diagnosis, treatment, and follow-up of these patients. Sensitization to allergens is detected using in vitro techniques such as measurement of specific IgE (radioallergosorbent test, or RAST) and also by in vivo tests, such as skin tests, to determine immediate hypersensitivity. ${ }^{19}$

Several allergens may be tested through cutaneous tests and RAST. However, mites are the main constituents of domiciliary dust and the allergens that cause more awareness and respiratory symptoms among atopic patients in the city of Curitiba. The main mites found in this city are the Dermatophagoides pteronyssinus (Pyroglyphidae family) and the Blomia tropicalis (Glycyphagidae family). There is a predominance of the D. pteronyssinus (65\%) over the B. tropicalis (30\%), as shown by the domiciliary dust mites study in which 384 domiciliary dirt samples were examined. ${ }^{20}$ Other allergens frequently tested are pollen, grasses, fungi, and cat and dog epithelium.

The RAST is allergen-specific and IgE immune-mediated. It is highly specific and less sensitive in addition to being more expensive than other types of tests available on the market, for example, the skin prick test. A laboratory blood test identifies IgE in a patient's blood. Therefore, the more IgE is present, the greater the allergic response to a specific antigen. Because it is a quantitative test, it is useful not only to make the diagnosis of allergy but also to take preventive measures and to monitor the efficacy of treatment and compliance. ${ }^{18}$ The RAST must be ordered in a rational way, based on history and physical examination, only if it is necessary.

The skin test is also very important in differential diagnosis of nasal disease and in determining the pattern of sensitization of the population. It is an important foundation for appropriate treatment of allergic rhinitis, particularly with regard to specific immunotherapy and also in promoting measures to reduce patient exposure to the allergen identified. For this test, patients are examined and treatment objectives are explained to the patient. The medial surface of the volar forearm is assessed to exclude dermal lesions and is wiped with $70 \%$ alcohol. A single drop of allergen extract is placed using the dropper, at a distance of $\sim 2 \mathrm{~cm}$, in a predetermined allergens sequence. A plastic device is used that limits the degree of penetration into the skin (PUNTOR, Alko do Brasil, Rio De Janeiro, Brazil) for each allergen. After 3 minutes, the excess extract is removed with a paper towel, avoiding contaminating neighboring tests. Reading takes place 15 to 20 minutes after the puncture. The presence of papules with diameters $\geq 3$ $\mathrm{mm}$ indicates a positive reaction, and results are graduated subjectively as light, moderate, or severe. The interruption in the use of the antihistamines is necessary for at least 7 days before a cutaneous test and the RAST. ${ }^{21}$

Allergic rhinitis treatment consists of an environmental control with withdrawal of the patient from the possible risk factors identified by the cutaneous test. Besides, the treatment may be associated with the application of topic nasal products based on corticoids and also on antihistamines.

Another form of therapy is based on the systemic response of the patient. The therapeutic modality focuses on specific immunotherapy and is more active against seasonal allergies. It is based on the administration of increasing doses of allergen-specific substances, and the individual's hypersensitivity reaction is mediated by $\operatorname{IgE} .^{22}$ This treatment may be effective in patients who persistently present signals and symptoms with traditional treatment. Furthermore, the immunotherapy may be discontinued after 45 years, when the IgE levels become elevated. The prognostic is extremely variable, and the symptoms may persist for up to 10 years in children. $^{18}$ 


\section{Aim}

The present study included patients 55 years or older with allergic rhinitis who had immunotherapy, and the efficiency of the specific-allergen immunotherapy was analyzed.

\section{Materials and Methods}

The present study was approved by the Ethics Committee and Research from Centro Médico Baptistella (CMEB) under protocol number 0015/2009.

\section{Design of the Experiment}

From June 2009 to July 2010, 104 charts of patients treated in CMEB 55 years or older with allergic complaints (including nasal obstruction, rhinorrhea, itching, and sneezing) were evaluated in Curitiba. The patients were selected by anamnesis, physical examination, and otorhinolaryngologic exam. All the patients had the cutaneous test for mites before and after 1 year of sublingual specific immunotherapy. The cutaneous response was classified as negative (absent), light, moderate, or severe.

\section{Sample}

The final sample included 104 patients aged 55 years or older. The medium age was 64.5 years, with 55 years and 74 years being the minimum and maximum, respectively. There were 73 (70.2\%) female and 31 (29.8\%) male patients.

Patients undergoing treatment for other comorbidities and/or taking other continuous medication were excluded.

\section{Allergic Tests}

The cutaneous test was used before and 1 year after the beginning of the immunotherapy. It was used a mixture of two mites: $D$. pteronyssinus and $B$. tropicalis, both of which are triggers of allergic symptoms in patients residing in Curitiba. Using a dropper, a single drop of the allergen extract was placed above the medial surface of the foreman at a distance of $\sim 2 \mathrm{~cm}$. After 3 minutes, the excess was removed with a paper towel and the reading took place after 15 minutes. The response was measured as negative (no papule), mild (papule $<4 \mathrm{~mm}$ ), moderate (papule 4 to $6 \mathrm{~mm}$ ), or severe (papule $>6 \mathrm{~mm}$ ), according to the local reaction unleashed by the allergen in the patient's skin.

\section{Allergen-Specific Immunotherapy}

Based on allergy test, three sublingual vaccine vials in different concentrations were used. Each 8-mL bottle was diluted as $1: 100,000,1: 10,000$, or $1: 1,000$. Doses were given three times per week (Monday, Wednesday, and Friday). The ideal treatment lasted $\sim 2$ years and consisted of drops administered sublingually incrementally on the aforementioned days of the week ( - Table 1 ).

\section{Results}

The cutaneous test before vaccination showed 42 patients with severe index, the equivalent of $40.4 \%$ of the sample, and 62 patients with moderate index, representing 59.6\% of the total, as shown by - Fig. 1. After the specific immunotherapy, 40 patients (38.4\%) were classified as negative for the allergen, 37 (35.6\%) had light response, 19 patients (18.3\%) had moderate response, and 8 (7.7\%) had severe response to the allergen, as shown by - Fig. 2 .

\section{Discussion}

Immunotherapy, a desensitization technique, is indicated in special cases when the patient cannot avoid allergen

Table 1 Schedule of allergen-specific immunotherapy

\begin{tabular}{|l|l|l|l|l|}
\hline & Day & $\begin{array}{l}\text { Phase 1 (1:100,000), } \\
\text { number of drops }\end{array}$ & $\begin{array}{l}\text { Phase 2 (1:10,000), } \\
\text { number of drops }\end{array}$ & $\begin{array}{l}\text { Phase 3 (1:1000), } \\
\text { number of drops }\end{array}$ \\
\hline $1 \mathrm{wk}$ & 1 & 1 & 1 \\
\hline & Monday & 2 & 2 & 2 \\
\hline & Wednesday & 3 & 3 & 3 \\
\hline $2 \mathrm{wk}$ & Friday & 4 & 4 & 4 \\
\hline & Monday & 4 & 5 & 5 \\
\hline & Wednesday & 5 & 6 & 6 \\
\hline $3 \mathrm{wk}$ & Friday & 6 & 7 & 7 \\
\hline & Monday & 7 & 8 & 8 \\
\hline & Wednesday & 8 & 9 & 9 \\
\hline $4 \mathrm{wk}$ & Friday & 9 & 10 & 10 \\
\hline & Monday & 10 & 11 & 11 \\
\hline & Wednesday & 11 & 12 & 12 \\
\hline $5 \mathrm{wk}$ & Friday & 12 & 13 & 13 \\
\hline & Monday & 13 & 14 & 14 \\
\hline & Wednesday & 14 & 15 & 15 \\
\hline & Friday & 15 & \multicolumn{2}{l}{} \\
\hline
\end{tabular}




\section{SEVERE MODERATE}

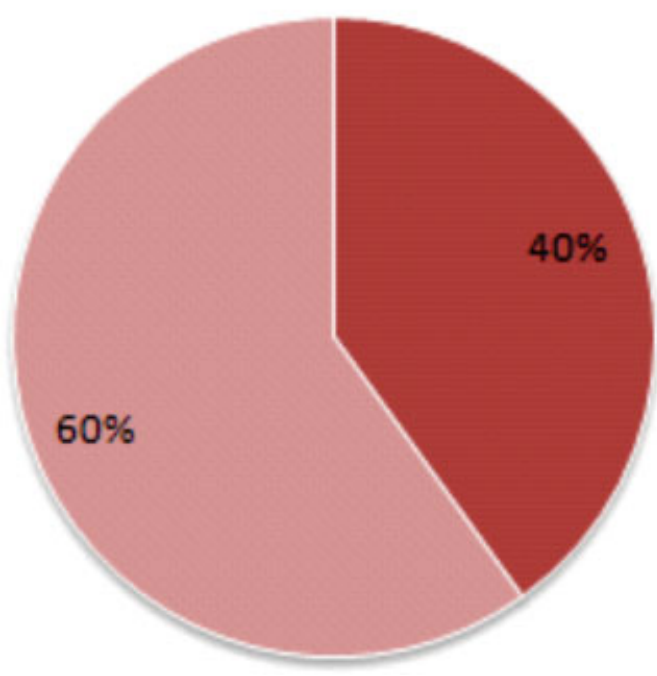

Fig. 1 Skin test response prior to allergen-specific immunotherapy.

\section{- SEVERE $\quad$ MODERATE MILD NEGATIVE}

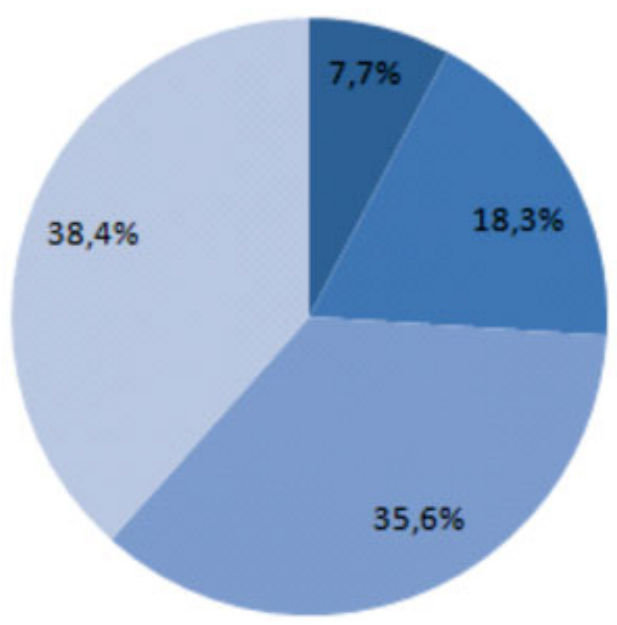

Fig. 2 Skin test response after allergen-specific immunotherapy.

exposition and in situations when there is no appropriate response to pharmacologic treatment. Although not including specific vaccination on elderly people in the literature, the present study demonstrates that immunotherapy for allergic rhinitis in this age group is safe and effective.

The European Academy of Allergy and Clinical Immunology advises specific vaccination as a relative contraindication for elderly patients with allergic rhinitis. ${ }^{23}$ The II Brazilian Consensus about Rhinitis, from $2006,{ }^{24}$ on the other hand, affirmed that, in rare cases, immunotherapy may be used in seniors. However, details about possible specifications were not provided. The Canadian Society of Allergy and Clinical Immunology, ${ }^{25}$ in its guidelines for the use of immunotherapy, does not contraindicate this treatment for aged patients.
In the present study we noticed the benefits of specific immunotherapy for the treatment of allergic rhinitis in elderly patients. During the evaluation of the 104 patients submitted to this therapeutic modality, there were no side effects. Moreover, the therapeutic evolution could be observed based on the cutaneous test.

The divergences found in the literature regarding both contraindications to the various treatment times and allergen-specific administrations and the results achieved in this study show the need for further research in this area to confirm that allergen-specific immunotherapy is an alternative treatment for allergic rhinitis in patients aged 55 years or older in whom conventional drug treatment and environmental control were not sufficient treatment of the chronic disease in question.

\section{References}

1 Machado PP. O baú dos sonhos adormecidos: a dimensão simbólica da rinite alérgica em um estudo de caso. Bol Psicol 2007;57 (126):89-106

2 McEwen BS. Physiology and neurobiology of stress and adaptation: central role of the brain. Physiol Rev 2007;87:873-904

3 Graham JE, Christian LM, Kiecolt-Glaser JK. Stress, age, and immune function: toward a lifespan approach. J Behav Med 2006; 29:389-400

4 Miller RA, Garcia G, Kirk CJ, Witkowski JM. Early activation defects in T lymphocytes from aged mice. Immunol Rev 1997;160:79-90

5 Pawelec G, Hirokawa K, Fülöp T. Altered T cell signalling in ageing. Mech Ageing Dev 2001;122:1613-1637

6 Fulop T, Larbi A, Douziech N, Levesque I, Varin A, Herbein G. Cytokine receptor signalling and aging. Mech Ageing Dev 2006;127:526-537

7 Bonagura VR, Hatam L, DeVoti J, Zeng F, Steinberg BM. Recurrent respiratory papillomatosis: altered $\mathrm{CD} 8(+) \mathrm{T}$-cell subsets and $\mathrm{T}(\mathrm{H})$ 1/T(H)2 cytokine imbalance. Clin Immunol 1999;93:302-311

8 Rizzo LV, Belfort R Jr. Ocular autoimmunity. In: Lahita RG, Chiorazzi N, Reeves WH, eds. Textbook of the Autoimmune Diseases. Philadelphia, PA: Lippincott Williams \& Wilkins; 2000:515

9 Amadori A, Zanovello P, Cozzi E, et al. Study of some early immunological parameters in aging humans. Gerontology 1988; 34:277-283

10 Ewers I, Rizzo LV, Kalil F. Imunologia e envelhecimento. Einstein 2008;6(Suppl 1):S13-S20

11 Silva TM. Perfil das Citocinas IL4, IL5, IL8e IFN-ã Analisadas por T-PCR em Tecido de Mucosa Nasal de Pacientes Portadores de Rinite Alérgica. [Dissertação (mestrado)]. Belo Horizonte, Brazil: Universidade Federal de Minas Gerais, Faculdade de Medicina; 2007

12 Ibiapina Cda C, Sarinho ES, Camargos PA, Andrade CR, Cruz Filho AA. Allergic rhinitis: epidemiological aspects, diagnosis and treatment. J Bras Pneumol 2008;34(4):230-240

13 Megid CBC, Cury PM, Cordeiro JA, Jorge RBB, Saidah R, Silva JBG. Tratamento da Rinite Alérgica: comparação da acunpuntura e corticóide nasal. Acta ORL 2006;24(2):61-66

14 Benson M, Strannegård IL, Wennergren G, Strannegård O. Interleukin-5 and interleukin-8 in relation to eosinophils and neutrophils in nasal fluids from school children with seasonal allergic rhinitis. Pediatr Allergy Immunol 1999;10:178-185

15 Mygind N, ed. Allergic and Nonallergic Rhinitis: Clinical Aspects. Philadelphia, PA: Saunders; 1993

16 Bradding P, Feather IH, Wilson S, et al. Immunolocalization of cytokines in the nasal mucosa of normal and perennial rhinitic subjects. The mast cell as a source of IL-4, IL-5, and IL-6 in human allergic mucosal inflammation. J Immunol 1993;151:3853-3865 
17 Durham SR, Ying S, Varney VA, et al. Cytokine messenger RNA expression for IL-3, IL-4, IL-5, and granulocyte/macrophage-colony-stimulating factor in the nasal mucosa after local allergen provocation: relationship to tissue eosinophilia. J Immunol 1992;148:2390-2394

18 Baptistella E, Trotta F, Silva TP, et al. Revisão da literatura e estudo retrospectivo de 670 pacientes com rinite alérgica. ACTA ORL/ Técnicas em Otorrinolaringologia 2009;27:85-88

19 Lopes MI, Miranda PJ, Sarinho E. Use of the skin prick test and specific immunoglobulin $\mathrm{E}$ for the diagnosis of cockroach allergy. J Pediatr (Rio J) 2006;82(3):204-209

20 Rosário Filho NA, Baggio D, Suzuki MM, Thomaz PCP, Sugisawa S, Hanggi V. Ácaros na poeira domiciliar em Curitiba [Abstract]. Rev Bras Alerg Imunopatol 1992;25:15-25
21 Godinho R, Lanza M, Godinho A, Rodriques A, Assiz TML. Freqüência de positividade em teste cutâneo para aeroalérgenos. Rev Bras Otorrinolaringol (Engl Ed) 2003;69(6):824-828

22 Associação Brasileira de Alergia e Imunopatologia e Sociedade Brasileira de Pediatria. Projeto Diretrizes. In: Imunoterapia alérgeno-específica. Projeto Diretrizes. Julho 2011

23 Mailing H, Weeke B; Position Paper of the European Academy of Allergy and Clinical Immunol. Position paper: immunotherapy. Allergy 1993;48(14, Suppl):9-35

24 Solé D, Mello Jr JF, Weckx LLM, et al. II Consenso Brasileiro sobre Rinites. Rev Bras Alerg Imunopatol 2006;29(1):29-58

25 Guidelines for the Use of Allergen Immunotherapy.. Canadian Society of Allergy and Clinical Immunology. Available at: http:// www.csaci.ca/index.php?page=361. Accessed May 22, 2011 